\title{
Antibiotic resistance and enterotoxin genes in Staphylococcus sp. isolates from polluted water in Southern Brazil
}

\author{
ANA P. BASSO, PAULA D. MARTINS, GISELE NACHTIGALL, \\ SUELI VAN DER SAND, TIANE M. DE MOURA and ANA PAULA G. FRAZZON
}

Programa de Pós-Graduação em Microbiologia Agrícola e do Ambiente, Universidade Federal do Rio Grande do Sul, Campus Central, Rua Sarmento Leite, 500, 90050-170 Porto Alegre, RS, Brasil

Manuscript received on December 19, 2013; accepted for publication on May 28, 2014

\begin{abstract}
The aim of this study was to evaluate the species distribution, antibiotic-resistance profile and presence of enterotoxin (SE) genes in staphylococci isolated from the Dilúvio stream in South Brazil. Eighty-eight staphylococci were identified, $93.18 \%$ were identified as coagulase-negative (CNS) and $6.82 \%$ coagulasepositive (CPS). Fourteen Staphylococcus species were detected and the most frequently were Staphylococcus cohnii (30.48\%) and S. haemolyticus (21.95\%). Resistance to erythromycin was verified in $37.50 \%$ of the strains, followed by $27.27 \%$ to penicillin, $12.50 \%$ to clindamycin, $6.81 \%$ to trimethoprim-sulfamethoxazole, $5.68 \%$ to chloramphenicol and $2.27 \%$ to norfloxacin. None of the investigated strains showed gentamicin and ciprofloxacin resistance. The strains were tested for the presence of sea, seb, sec, sed and see genes by PCR and only CNS strains (43.18\%) showed positive results to one or more SE genes. The scientific importance of our results is due to the lack of data about these topics in polluted waters in Brazil. In conclusion, polluted waters from the Dilúvio stream may constitute a reservoir for disseminating antibiotic-resistance and enterotoxin into the community. In addition, the detection of staphylococci in the polluted waters of the Dilúvio stream indicated a situation of environmental contamination and poor sanitation conditions.
\end{abstract}

Key words: coagulase negative staphylococcus, coagulase-positive staphylococcus, antibiotic resistant staphylococcus, enterotoxin genes, polluted water.

\section{INTRODUCTION}

Microbiological water contamination is one of the biggest public health problems in the world. The World Health Organization (WHO) estimates that around one billion people drink unsafe water and approximately three million people die each year from waterborne diseases (Omari and YeboahManu 2012). The Dilúvio is a polluted stream that crosses the city of Porto Alegre, the state capital of

Correspondence to: Ana Paula Guedes Frazzon

E-mail: ana.frazzon@ufrgs.br
Rio Grande do Sul, the $10^{\text {th }}$ most populous city in Brazil, with approximately 1,500,000 inhabitants. The Dilúvio stream flows into the Guaíba Lake, the main source of water supply to Porto Alegre which is also used for water-based sports, such as sailing, kayaking, canoeing, powerboating and windsurfing (Devos 2009).

Staphylococcus species are ubiquitously distributed in nature (Varnam and Evans 1996) and resistant strains have been isolated from diverse sources, such as foods, animals and healthy and 
hospitalized individuals (Malik et al. 2005, Sorum and L'Abee-Lund 2002, Wisplinghoff et al. 2004). Members of the Staphylococcus genus can express a wide range of virulence factors, such as: cell wall components, proteases, coagulase, hemolysins, enterotoxins, toxic-shock syndrome (TSS) and exfoliatins toxin (Novick et al. 2001).

Staphylococcal Enterotoxins (SEs) are part of the pyrogenic proteins associated to many human diseases (Pinchuk et al. 2010). These proteins are resistant to thermal inactivation and to gastrointestinal proteases, causing emesis and diarrhae, and/or can act as superantigens (Balaban and Rasooly 2000, Pinchuk et al. 2010). Although more than 20 different enterotoxins were identified, only the classical enterotoxins, like SEA, SEB, SEC, SED and SEE were well studied (Goto et al. 2007). These enterotoxins are generally produced by Staphylococcus aureus, but other species, such as $S$. intermedius, S. hyicus, S. xylosus and $S$. epidermidis can also express them (Bhatia and Zahoor 2007).
In Brazil, numerous studies have been published about staphylococci, but so far there are no studies that evaluate staphylococci in polluted water. Therefore, the aim of this study was to evaluate staphylococci species distribution, antibiotic resistance profile and enterotoxin genes frequency in Staphylococcus sp. isolated from polluted water from the Dilúvio stream in South Brazil.

\section{MATERIALS AND METHODS}

\section{STUDy AREA AND SAMPLING OF WATER}

The study sites were randomly selected within the Dilúvio stream in Porto Alegre, RS, Brazil ( $30^{\circ} 1^{\prime}$ $40^{\prime \prime}$ South, $51^{\circ} 13^{\prime} 43^{\prime \prime}$ West). The water samples $(500 \mathrm{~mL})$ were collected at five different points (Sites A to E), as described by Nachtigall et al. 2013 (Figure 1). The samples were collected aseptically, taken directly from the superficial water in sterilized glass bottles and transported to the laboratory under refrigeration $\left(4^{\circ} \mathrm{C}\right)$. Aliquot of $1 \mathrm{~mL}$ were placed in $9 \mathrm{ml}$ of sterile water in a sterile test tube, and initial

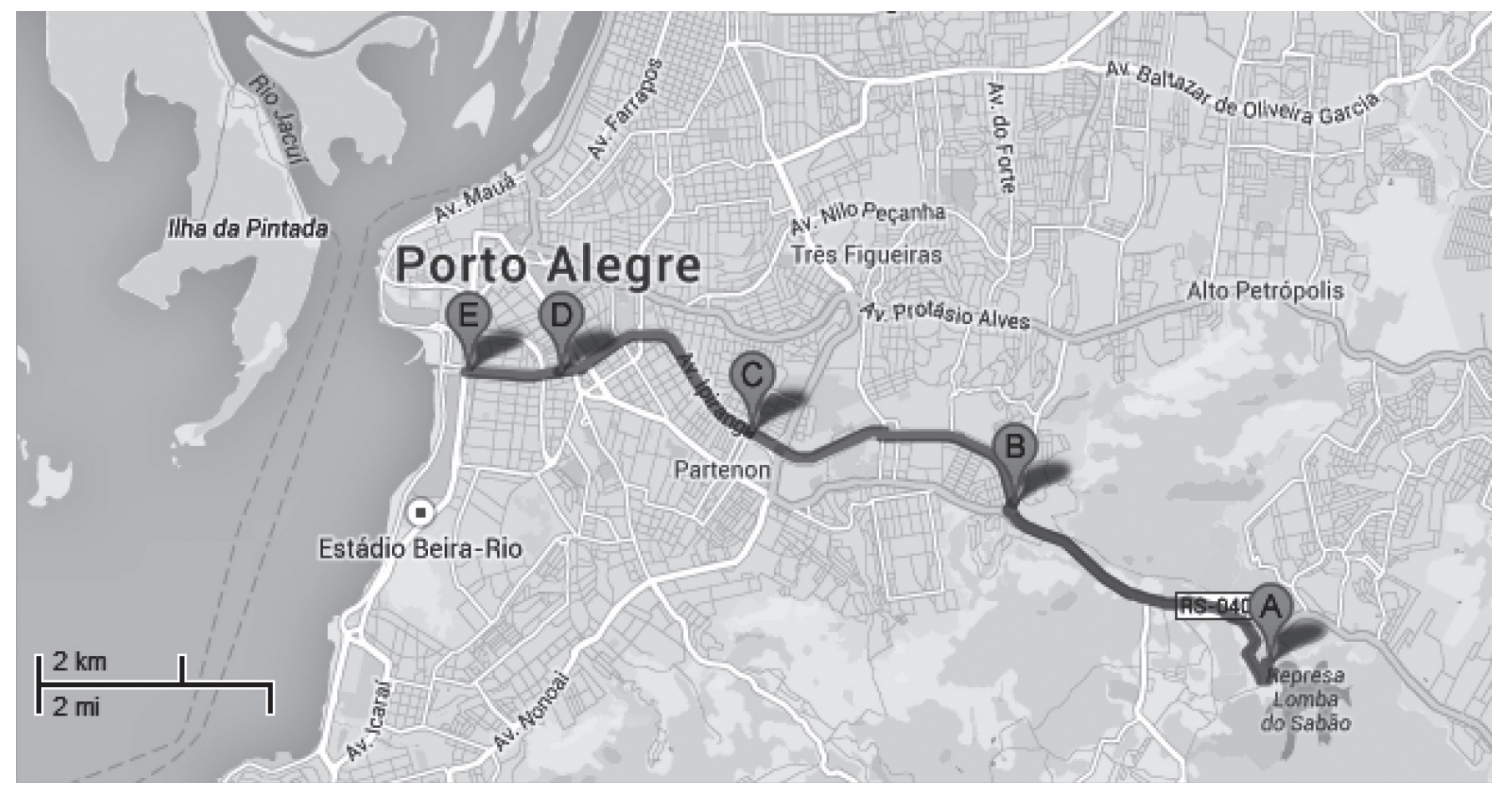

Figure 1 - Map of the study areas and sampling sites into Dilúvio stream in Porto Alegre, RS, Brazil: Site A: headwaters in the Saint Hilaire Park; Site B: Ipiranga Av. corner Antônio de Carvalho Av.; Site C: Ipiranga Av. corner Guilherme Alves St; Site D: Ipiranga Av. corner Ramiro Barcelos St and Site E: Ipiranga Av. corner Borges de Medeiros Av. Source: Google Maps. [Accessed 05/12/2013]. 
samples were further 10 -fold diluted to obtain a final dilution factor of 1/1000. From each dilution, $200 \mu 1$ were inoculated into Salt-Mannitol agar and incubated at $37^{\circ} \mathrm{C}$ for $24 \mathrm{~h}$.

\section{Conventional Phenotypic Testing And AntiBiotic}

SuscePTIBILITY TESTS

Twenty-four colonies from each water sample were selected. Phenotypic criteria such as size/volume, shape, color, Gram staining, growth in SaltMannitol agar and catalase production were used to confirm genus. Coagulase, Vogues-Proskauer (VP) and sugar fermentation tests, detection of urease and oxidase enzymes, nitrate reduction, and susceptibility to Polymyxin B and Novobiocin were used for species identification, according to MacFaddin (2000). The samples were individually stored in BHI broth $20 \%$ glycerol at $-20^{\circ} \mathrm{C}$. The $S$. aureus ATCC 25923 and ATCC 19095 were used as positive controls. The strains were individually stored in BHI broth $20 \%$ glycerol at $-20^{\circ} \mathrm{C}$.

Antibiotic susceptibility tests were carried out according to the Clinical and Laboratory Standards Institute (CLSI 2013) by the Disc-Diffusion Method (Bauer et al. 1966). The following antimicrobials were used: Penicillin (10 U), Erythromycin (15 $\mu \mathrm{g})$, Clindamycin (2 $\mu \mathrm{g})$, Trimethoprimsulfamethoxazole $(25 \mu \mathrm{g})$, Chloramphenicol $(30 \mu \mathrm{g})$, Ciprofloxacin $(5 \mu \mathrm{g})$, Gentamicin $(10 \mu \mathrm{g})$ and Norfloxacin $(10 \mu \mathrm{g})$. All tests were performed in triplicates. The strain S. aureus ATCC 25923 was used as control.

\section{Detection of Staphylococcal EnTERotoxins Genes}

DNA extractions and polymerase chain reaction (PCRs) for five classical staphylococcal enterotoxins genes (sea, seb, sec, sed and see) were performed as previously described by Moura et al. 2012. The $S$. aureus ATCC 13565, ATCC 14458, ATCC 19095, ATCC 23235 and ATCC 27664 strains were used as positive controls for sea, seb, sec, sed and see genes, respectively.

\section{RESULTS AND DISCUSSION}

Eighty-eight samples (73.33\%) from a total of 120 strains were staphylococci, and of these, 82 (93.18\%) were characterized as coagulase-negative staphylococci (CNS) and $6(6.82 \%)$ as coagulasepositive staphylococci (CPS) (Table I). In the CNS group, the 11 species most frequently detected in polluted water were Staphylococcus cohnii (30.48\%) S. haemolyticus (21.95\%), S. carnosus $(12.19 \%), \quad S$. saprophyticus $(9.75 \%), \quad$ S. sciuri group (7.31\%), S. hominis (3.65\%), S. gallinarium (3.65\%), S. muscae (2.43\%), S. caprae (2.43\%), S. cromogenes $(2.43 \%)$, and $S$. felis $(1.21 \%)$. In the CPS group, S. aureus subsp. aureus (16.66\%), $S$. delphini (16.66\%) and S. intermedius (16.66\%) were identified. Three CNS and 3 CPS isolates could not be identified as a species level and were classified as Staphylococcus sp.

Staphylococcus are a genre of bacteria widespread in nature, being found in the air, soil, water, food products and animals, including human beings (Faria et al. 2009, Hou et al. 2012, Martins et al. 2013). In this study the frequency to CNS species was higher than CPS, this result agrees with Serapicos (2008) and Faria et al. (2009) who also demonstrated an elevated frequency of CNS in wastewater. The presence of staphylococi species in polluted waters of the Dilúvio stream can be justified, since members of the Staphylococcus genus commonly inhabit the intestinal tract of humans and warm-blooded animals and they contaminate the surface waters through inadequate septic tanks, wastewater effluents, and fecal discharges (Orrett and Shurland 1998).

The distribution of staphylococci species isolated from water samples obtained from different sites of the Dilúvio stream is shown in Table I. A wide variety of staphylococci species was isolated from Sites B, C, D and E, while from Site A, no staphylococci were isolated. The region of Site $\mathrm{A}$ is considered the headwaters of the Dilúvio 
TABLE I

Distribution of staphylococci species isolated from polluted water samples obtained from different sites of the Dilúvio stream in South Brazil.

\begin{tabular}{ccccccc}
\hline & \multicolumn{6}{c}{ Number of staphylococci species isolates in Site: } \\
\hline Species & A & B & C & D & E & Total \\
\hline Coagulase-negative & & & & & & \\
S. conhii & 0 & 6 & 10 & 5 & 4 & 25 \\
S. haemolyticus & 0 & 6 & 6 & 3 & 3 & 18 \\
S. carnosus & 0 & 1 & 2 & 2 & 5 & 10 \\
S. saprophyticus & 0 & 2 & 0 & 2 & 4 & 8 \\
S. sciuri group & 0 & 2 & 1 & 2 & 0 & 5 \\
S. hominis & 0 & 0 & 0 & 1 & 2 & 3 \\
S. gallmarium & 0 & 0 & 1 & 2 & 0 & 3 \\
S. muscae & 0 & 1 & 1 & 0 & 0 & 2 \\
S. caprae & 0 & 0 & 2 & 0 & 0 & 2 \\
S. cromogenes & 0 & 1 & 1 & 0 & 0 & 2 \\
S. felis & 0 & 0 & 0 & 1 & 0 & 1 \\
Staphylococcus sp. & 0 & 0 & 0 & 1 & 2 & 3 \\
\hline Coagulase-positive & & & & & & \\
S. aureus subsp. aureus & 0 & 0 & 1 & 0 & 0 & 1 \\
S. delphini & 0 & 0 & 0 & 1 & 0 & 1 \\
S. intermedius & 0 & 0 & 0 & 0 & 1 & 1 \\
Staphylococcus sp. & 0 & 1 & 0 & 2 & 0 & 3 \\
\hline Total & $\mathbf{0}$ & $\mathbf{2 0}$ & $\mathbf{2 5}$ & $\mathbf{2 2}$ & $\mathbf{2 1}$ & $\mathbf{8 8}$ \\
(\%) & $\mathbf{( 0 \% )}(\mathbf{2 2 . 7 2 \% )} \mathbf{( 2 8 . 4 0 \% )}$ & $\mathbf{( 2 5 \% )}$ & $\mathbf{( 2 3 . 8 6 \% )}$ & \\
\hline & & & & & &
\end{tabular}

stream located in the Saint Hilaire Park, which is the area with the lowest anthropic influence. Site $\mathrm{B}$ is located in an urbanized area, where many residential homes are not connected to a public sanitary sewer system. In addition, Site B also has domestic animals, such as cows, horses, chickens and pigs, which are used for food or labor, and the feces of these animals drain directly into the stream, being a recognized source of contamination. Sites C, D and E were located in a dense urban area, with hospitals, schools, restaurants, universities and residential homes. The occurrence of staphylococci species in these sites, can be explained due to the fact that the sanitary sewer system of many places remain connected to the urban fluvial channel, contributing significantly to the contamination of the Dilúvio's stream (Nachtigall et al. 2013).

Table II shows the antibiotic resistance of Staphylococcus species isolated from polluted water. Resistance to erythromycin was verified in $37.50 \%$ of the strains, followed by $27.27 \%$ to penicillin, $12.50 \%$ to clindamycin, $6.81 \%$ to trimethoprim-sulfamethoxazole, $5.68 \%$ to chloramphenicol and $2.27 \%$ to norfloxacin. None of the investigated Staphylococcus strains showed gentamicin and ciprofloxacin. Isolates resistant to two or more classes of antimicrobials were classified as multiresistant and accounted for $10.2 \%$ of all isolates.

The Dilúvio's stream receives contaminants from both natural and anthropogenic sources. In this study, staphylococci strains showed resistances to antibiotics commonly used in human and veterinary medicine to treat infectious diseases caused by Gram-positive bacteria, like penicillin and erythromycin. Penicillin is the antibiotic of choice in most staphylococcal infections, and clindamycin and erythromycin are alternative 
TABLE II

Number of antibiotic-resistant staphylococci isolates from polluted water.

\begin{tabular}{|c|c|c|c|c|c|c|c|c|}
\hline \multirow{2}{*}{ Species (n) } & \multicolumn{8}{|c|}{ Number of resistant strains for each antibiotic } \\
\hline & ERY & PEN & CLI & SUT & CHL & NOR & CIP & GEN \\
\hline S. conhii (25) & 7 & 5 & 1 & 0 & 0 & 0 & 0 & 0 \\
\hline S. haemolyticus (18) & 5 & 6 & 3 & 3 & 1 & 1 & 0 & 0 \\
\hline S. saprophyticus (8) & 3 & 1 & 0 & 1 & 1 & 0 & 0 & 0 \\
\hline S. carnosus (10) & 7 & 4 & 4 & 1 & 2 & 0 & 0 & 0 \\
\hline S. hominis (3) & 1 & 2 & 0 & 1 & 0 & 0 & 0 & 0 \\
\hline S. muscae (2) & 1 & 0 & 0 & 0 & 0 & 1 & 0 & 0 \\
\hline S. gallinarium (3) & 1 & 0 & 0 & 0 & 1 & 0 & 0 & 0 \\
\hline S. caprae (2) & 1 & 1 & 1 & 0 & 0 & 0 & 0 & 0 \\
\hline S. cromogenes (2) & 0 & 0 & 0 & 0 & 0 & 0 & 0 & 0 \\
\hline S. aureus subsp. aureus (1) & 0 & 1 & 0 & 0 & 0 & 0 & 0 & 0 \\
\hline S. delphini (1) & 0 & 1 & 0 & 0 & 0 & 0 & 0 & 0 \\
\hline S. intermedius (1) & 1 & 1 & 0 & 0 & 0 & 0 & 0 & 0 \\
\hline S. felis (1) & 1 & 0 & 1 & 0 & 0 & 0 & 0 & 0 \\
\hline S. sciuri group (5) & 3 & 1 & 0 & 0 & 0 & 0 & 0 & 0 \\
\hline CNS (3) & 2 & 1 & 1 & 0 & 0 & 0 & 0 & 0 \\
\hline CPS (3) & 0 & 0 & 0 & 0 & 0 & 0 & 0 & 0 \\
\hline Total & 33 & 24 & 11 & 6 & 5 & 2 & $\mathbf{0}$ & $\mathbf{0}$ \\
\hline$(\%)$ & $(37.50 \%)$ & $(27.27 \%)$ & $(12.50 \%)$ & $(6.81 \%)$ & $(5.68 \%)$ & $(2.27 \%)$ & $(0 \%)$ & $(0 \%)$ \\
\hline
\end{tabular}

ERY: erythromycin (15 $\mu \mathrm{g})$; PEN: penicillin (10 UI); CLI: clindamycin (10 $\mu \mathrm{g})$; SUT: trimethoprim - sulfamethoxazole (25 $\mu \mathrm{g})$; CHL: chloranphenicol $(30 \mu \mathrm{g})$; NOR: norfloxacin $(10 \mu \mathrm{g})$; CIP: ciprofloxacin $(5 \mu \mathrm{g})$; GEN: gentamicin $(10 \mu \mathrm{g})$.

agents in patients who are allergic to penicillin (Dryden 2010). Previous studies, also reported antibiotic resistance in staphylococci isolated from wastewater, polluted and drinking water. Kessie et al. (1998) also identified CNS resistant to chloramphenicol and erythromycin isolated from polluted water. Serapicos (2008) observed a high frequency of staphylococci resistance to lincomycin, eritrhomicyn and clindamycin, while a low frequency of isolates were resistant to penicillin in water collected from a wastewater treatment plant. Faria et al. (2009) have encountered a high frequency of CNS resistant to erythromycin, beta-lactams, tetracycline, clindamycin and erythromycin in wastewater and drinking water. In sea water, freshwater and sediments samples from the Lebanon coast, resistant staphylococci were also isolated, where $51 \%$ of them were resistant to at least one tested antimicrobial (Harakeh et al. 2006).
Multiresistant staphylococci were also detected in potable water from Pakistan and from the United States (Armstrong et al. 1981, Samra et al. 2009). Recently, antibiotic-resistant staphylococci were isolated after sewage treatment (He $\beta$ et al. 2013).

All strains were tested for the presence of sea, seb, sec, sed and see by PCR, and only $43.18 \%$ CNS strains showed positive PCR results to one or more enterotoxins genes. The sec was present in $52.63 \%$ (20/38), followed by $18.42 \%$ to sea $(7 / 38)$, 13.15 to see (5/38), $10.52 \%$ to sed (4/38) and $5.26 \%$ to seb (2/38) (Table III). Two strains harbored two genes simultaneously.

Staphylococcal enterotoxins (SE) constitute a family of biologically and structurally related toxins and the ingestion of these toxins results in gastrointestinal effects such as nausea, vomiting, diarrhea, and abdominal pain. The SE are the main cause of bacterial food poisoning in human 
TABLE III

Distribution of enterotoxin genes in staphylococcus isolated from polluted water in South Brazil.

\begin{tabular}{cccccc}
\hline $\begin{array}{c}\text { Species } \\
(\mathbf{n = 3 8})\end{array}$ & \multicolumn{5}{c}{ Number of isolates positives for enterotoxin genes by PCR } \\
\cline { 2 - 5 } S. conhii & 3 & seb & sec & sed & see \\
S. haemolyticus & 1 & 0 & 13 & 2 & 4 \\
S. saprophyticus & 0 & 1 & 3 & 1 & 0 \\
S. carnosus & 2 & 0 & 1 & 0 & 0 \\
S. muscae & 0 & 0 & 1 & 0 & 1 \\
S. caprae & 1 & 0 & 0 & 1 & 0 \\
S. sciuri group & 0 & 0 & 0 & 0 & 0 \\
\hline Total & 7 & 1 & 2 & 0 & 0 \\
(\%) & $\mathbf{( 1 8 . 4 2} \%)$ & $\mathbf{( 5 . 2 6 \% )}$ & $\mathbf{( 5 2 . 6 3 \% )}$ & $\mathbf{( 1 0 . 5 2} \%)$ & $\mathbf{( 1 3 . 1 5} \%)$ \\
\hline
\end{tabular}

beings and have been described as the cause of many outbreaks of foodborne diseases (Lamaita et al. 2005). All five classical enterotoxin genes were detected in the present work, in which $43.18 \%$ CNS strains were positive to one or more tested genes. The SE frequency observed here was compared to food samples, because until to date there are no studies that evaluate the presence of SE in water. Some studies have shown that CNS strains can harbor enterotoxins genes. Moura et al. (2012) reported the presence of enterotoxins genes in CNS strains isolated from black pudding. The SE genes were also detected in coagulase negative staphylococci isolated from dairy products in Brazil (Rall et al. 2010). The same was observed by Cunha et al. (2006) in a study that evaluated 88 CNS strains isolates from different types of foods. The sec gene was the most prevalent among staphylococci isolated from polluted water in the Dilúvio stream, when compared to sea, see, sed, and seb genes. One explanation for these results could be related to the fact that the Dilúvio stream receives discharge from animal and human sewage and SEC toxin is frequently isolated from animal and human sources (Rosec and Gigaud 2002). Otherwise, SEA, SEB, SEE and SED toxins are associated with food poisoning (Pinchuk et al. 2010).

The scientific importance of our results is due to the lack of data about these topics in polluted water. The results, indicate that the occurrence of staphylococci antibiotic resistant and harboring enterotoxin genes in polluted waters from the Dilúvio stream, may constitute a reservoir for disseminating antibiotic-resistance and enterotoxin into the community, since Dilúvio's stream flows into the Guaiba Lake, which is the main source of water supply to Porto Alegre as well as being used for water-based sports. In addition, the detection of staphylococci in the polluted waters of the Dilúvio stream indicated a situation of environmental contamination by fecal microorganisms of human and animal origin and poor sanitation conditions.

\section{ACKOWLEDGEMENTS}

We thank the Conselho Nacional de Desenvolvimento Científico e Tecnológico do Brasil (CNPq) and the Coordenação de Aperfeiçoamento de Pessoal de Nível Superior (CAPES) of the Brazilian government, for the support received.

\section{RESUMO}

O objetivo deste estudo foi avaliar a distribuição das espécies, perfil de resistência a antibióticos e presença de enterotoxinas (SE) genes em estafilococos isolados do arroio Dilúvio no Sul do Brasil. Oitenta e oito estafilococos foram identificados, $93,18 \%$ foram identificados como coagulase negativa $(\mathrm{SCN})$ e $6,82 \%$ coagulase-positiva (SCP). Quatorze espécies de Staphylococcus foram 
detectados e as mais frequentes foram Staphylococcus cohnii (30,48\%) e S. haemolyticus (21,95\%). Resistência à eritromicina foi verificada em $37,50 \%$ das cepas, seguido por $27,27 \%$ de penicilina, $12,50 \%$ de clindamicina, $6,81 \%$ de trimetoprim-sulfametoxazol, 5,68\% a cloranfenicol e $2,27 \%$ a norfloxacina. Nenhuma das cepas investigadas mostrou resistência a gentamicina e ciprofloxacina. As cepas foram testadas para a presença dos genes sea, seb, sec, sed e see por PCR e somente as cepas SCN $(43,18 \%)$ apresentaram resultados positivos para um ou mais genes SE. A importância científica dos nossos resultados é devida à falta de dados sobre esses temas em águas poluídas no Brasil. Em conclusão, as águas poluídas do córrego Dilúvio podem constituir um reservatório de disseminação de resistência a antibióticos e enterotoxina na comunidade. Além disso, a detecção de estafilococos em águas poluídas do arroio do Dilúvio indicou uma situação de contaminação do ambiente e condições ruins de saneamento.

Palavras-chave: estafilococos coagulase negativo, estafilococos coagulase positiva, estafilococos resistente a antibióticos, genes enterotoxinas, água poluída.

\section{REFERENCES}

ARMstrong JL, SHigeno DS, CALOMIRIS JJ AND SEIDLER RJ. 1981. Antibiotic-resistant bacteria in drinking-water. Appl Environ Microbiol 42: 277-283.

BALABAN NAND RASOOLY A. 2000. Staphylococcal enterotoxins. Int J Food Microbio 61: 1-10.

BAUER AW, KirbY WMM, SHERris JC AND TURCK M. 1966. Antibiotic susceptibility testing by a standardized single disk method. Am J Clin Pathol 45: 493-496.

BHATIA A AND ZAHOOR S. 2007. Staphylococcus aureus Enterotoxins: A Review J Clin Diagn Res 1: 188-197.

CLSI - Clinical and Laboratory Standards Institute. 2013. Performance Standards for Antimicrobial Susceptibility Testing; Twenty-Third Informational Supplement. CLSI document M100-S23. Clinical and Laboratory Standards Institute, Wayne.

Cunha MLRS, Peresi E, CAlsolari RAO AND ARAúJo Jr JP. 2006. Detection of enterotoxins genes in coagulase-negative staphylococci isolated from foods. Braz J Microbiol 37: 70-74.

Devos RV. 2009. A crise ambiental sob a perspectiva da memória e dos itinerários no mundo urbano contemporâneo. Ambiente \& Sociedade XII: 293-306.

DRYDEN MS. 2010. Complicated skin and soft tissue infection. J Antimicrob Chemother 65(Suppl.3): iii35-44.
Faria C, VAZ-Moreira I, SERapicos E, Nunes OC AND MANAIA CM. 2009. Antibiotic resistance in coagulase negative staphylococci isolated from wastewater and drinking water. Sci Total Environ 407: 3876-3882.

Goto M, Hayashidani H, TAKatori K AND HaRA-Kudo Y. 2007. Rapid detection of enterotoxigenic Staphylococcus aureus harbouring genes for four classical enterotoxins, SEA, SEB, SEC and SED, by loop-mediated isothermal amplification assay. Lett Appl Microbiol 45: 100-107.

HARAKEH S, YASSINE H, HAJJAR S AND El-FAdEL M. 2006. Isolates of Staphylococcus aureus and saprophyticus resistant to antimicrobials isolated from the Lebanese aquatic environment. Mar Pollut Bull 52: 912-919.

Heß S, Winter J and Gallet C. 2013. Antibiotic-resistant staphylococci in the aquatic environment. In: $5^{\text {th }}$ Congress of European Microbiologists, Leipzing, Germany, p. 242.

Hou W, SUN X, WANG Z AND ZHANG Y. 2012. Biofilm-forming capacity of Staphylococcus epidermidis, Staphylococcus aureus, and Pseudomonas aeruginosa from ocular infections. Invest Ophthalmol Vis Sci 53: 5624-5631.

Kessie G, Ettayebi M, Haddad AM, Shibl AM, AlSHAMMARY FJ, TAWFIK AF AND AL-AHDAL MN. 1998. Plasmid profile and antibiotic resistance in coagulasenegative staphylococci isolated from polluted water. J Appl Microbiol 84: 417-422.

LAMAITA HC, CERQUEIRA MMOP, CARMO LS, SANTOS DA, PEnNa CFAM And Souza MR. 2005. Contagem de Staphylococcus sp. e detecção de enterotoxinas estafilocócicas e toxina da síndrome do choque tóxico em amostras de leite cru refrigerado. Arq Bras Med Vet Zoot 57: 702-709.

MACFADDIN JF. 2000. Biochemical Tests for Identification of Medical Bacteria, $3^{\text {rd }}$ ed., Lippicott Williams and Wilkins, Philadelphia. 912p.

MALIK S, PENG H AND BARTON MD. 2005. Antibiotic resistance in staphylococci associated with cats and dogs. J Appl Microbiol 99: 1283-1293.

MARTINS PD, ALMEIDA TT, BASSO AP, MOURA TM, FRAZZON J, TONDO EC AND FrAZzON APG. 2013. Coagulase-Positive Staphylococci Isolated from Chicken Meat: Pathogenic Potential and Vancomycin Resistance. Foodborne Pathog Dis 10: 771-776.

Moura TM, CAmpos FS, D'AzEVEdo PA, VAN Der SAND ST, Franco AC, FrazZon J AND FraZZON APG. 2012. Prevalence of enterotoxin-encoding genes and antimicrobial resistance in coagulase-negative and coagulase-positive Staphylococcus isolates from black pudding in Southern Brazil. Rev Soc Bras Med Trop 45: 579-585.

Nachtigall G, Jesus AG, Angelis D, Santestevan NA, MinotTo E, Moura TM, D’Azevedo P, SAND STVD, FRAZZON J AND FRAZZON APG. 2013. Diversidade e perfil de susceptibilidade antimicrobiana de Enterococcus sp. isolados das águas do Arroio Dilúvio - Porto Alegre, RS, Brasil. R Bras Bioci 11: 235-241.

Novick RP, SCHLIEVERT P AND RuzIN A. 2001. Pathogenicity and resistance islands of staphylococci. Microbes Infect 3: 585-594. 
OMARI S AND YEBOAH-MANU D. 2012. The study of bacterial contamination of drinking water sources: A case study of Mpraeso, Ghana. Int J Microbiol 10(1): 1-6

ORRETT FA AND SHURLAND SM. 1998. Significance of coagulasenegative staphylococci in urinary tract infections in a developing country. Conn Med 62: 199-203.

PINCHUK IV, BeSWICK EJ AND REYES VE. 2010. Staphylococcal Enterotoxins. Toxins 2: 2177-2197.

Rall Vlm, Sforcin JM, De Deus MFD, De Sousa DC, Camargo CH, Godinho NC, Galindo LA, SoAres TCS AND ARAÚJO JP. 2010. Polymerase chain reaction detection of enterotoxins genes in coagulase-negative staphylococci isolated from brazilian minas cheese. Foodborne Pathog Dis 7: 1121-1123.

RoseC JP AND GIGAUD O. 2002. Staphylococcal enterotoxin genes of classical and new types detected by PCR in France. Int J Food Microbiol 77: 61-70.

SAMRA ZQ, NASEEM M, KHAN SJ, DAR N AND ATHAR MA 2009. PCR Targeting of antibiotic resistant bacteria in public drinking water of Lahore Metropolitan, Pakistan. Biomed Environ Sci 22: 458-463.
SERAPICOS ES. 2008. Prevalência da resistência a antibióticos, metais e desinfectantes em isolados de Staphylococcus provenientes de uma ETAR municipal. Porto. Dissertation. Departament of Chemistry. Universidade do Porto, Portugal, 2008, 97 p. (Unpublished).

SORUM H AND L'ABEE-LUND TM. 2002. Antibiotic resistance in food-related bacteria - a result of interfering with the global web of bacterial genetics. Int J Food Microbiol 78: 43-56.

VARNAM AH AND EVANS G. 1996. Foodborne pathogens: an illustrated text. University of Cornell, Manson, $557 \mathrm{p}$.

WisplinghofF H, BischofF T, TALlEnt SM, SEIFERT H, WENZEL RP AND EDMOND MB. 2004. Nosocomial bloodstream infections in US hospitals: Analysis of 24,179 cases from a prospective nationwide surveillance study. Clin Infec Dis 39: 309-317. 